\title{
ANALISIS MUTU (INPUT-PROSES-OUTPUT) PENDIDIKAN DI LEMBAGA PENDIDIKAN ISLAM MTS ASSALAM KOTA MATARAM NUSA TENGGARA BARAT
}

\author{
Luthfi Zulkarmain \\ Universitas Islam Negeri Sunan Kalijaga Yogyakarta \\ zulkarmainlutfi@gmail.com
}

\begin{abstract}
The MTs Assalam educational institution, Mataram City, NTB is a relatively new educational institution because it officially became an educational institution legally in 2019, but students and students there have shown enthusiasm and high motivation to learn whether it is in implementing programs implemented in Islamic boarding schools or at schools They are also active in several extra activities such as tabfidz, student council, scouting, silat and recitation, the policy that is implemented is that it requires all students and students to live in the but and free food and housing fees. This study aims to analyze in depth the quality and quality (input, process, and output) that exist in the MTs Assalam educational institution, Mataram City, West Nusa Tenggara. This research is a qualitative research with a phenomenological research type. The research instruments used were documentation and observation, data analysis used in this study was data reduction, data presentation and data verification. The results showed that the system of quality development process and the quality of students there is by compulsory boarding and following the rules of the boarding school, collaborating with lodges, collaborating with the community, holding recitations for the community, always coordinating with the santri guardians and building a network of partners with offices - government offices.
\end{abstract}

Keywords: Education, Quality, Input, Process, Output

\begin{abstract}
Abstrak : Institusi Pendidikan MTs Assalam Kota Mataram NTB merupakan institusi pendidikan yang tergolong baru karena resmi menjadi institusi pendidikan secara resmi pada tahun 2019, namun siswa dan siswa disana telah menunjukkan semangat dan motivasi yang tinggi untuk belajar baik dalam melaksanakan program-program yang dilaksanakan di pesantren. sekolah atau di sekolah Mereka juga aktif dalam beberapa kegiatan ekstra seperti tahfidz, OSIS, pramuka, silat dan pengajian, kebijakan yang diterapkan adalah mewajibkan semua siswa dan siswa untuk tinggal di gubuk dan gratis biaya makan dan tempat tinggal. Penelitian ini bertujuan untuk menganalisis secara mendalam kualitas dan kualitas (input, proses, dan output) yang ada di institusi pendidikan MTs Assalam, Kota Mataram, Nusa Tenggara Barat. Penelitian ini merupakan penelitian kualitatif dengan jenis penelitian fenomenologi. Instrumen penelitian yang digunakan adalah dokumentasi dan observasi, analisis data yang digunakan dalam penelitian ini adalah reduksi data, penyajian data dan verifikasi data. Hasil penelitian menunjukkan bahwa sistem proses pembinaan mutu dan mutu santri yang ada dengan wajib pesantren dan mengikuti aturan pondok pesantren, bekerjasama dengan pondok-pondok, berkolaborasi dengan masyarakat, mengadakan
\end{abstract}

Manazhim : Jurnal Manajemen dan Ilmu Pendidikan

Volume 3, Nomor 1, Februari 2021; 17-31

https://ejournal.stitpn.ac.id/index.php/manazhim 
pengajian untuk masyarakat, selalu berkoordinasi dengan wali santri. dan membangun jaringan rekanan dengan kantor - kantor pemerintahan.

Kata Kunci : Pendidikan, Kualitas, Input, Proses, Output

\section{PENDAHULUAN}

Mutu pendidikan sering disebut juga dengan kualitas pendidikan, meningkatkan mutu pendidikan adalah masalah pokok yang harus dimaksimalkan untuk meraih keberhasilan ditengah-tengah persaingan dunia pendidikan. Lembaga pendidikan di Indonesia masih menjadi harapan bangsa dalam mencetak generasi-generasi bangsa untuk masa depan, seiring peradaban zaman yang semakin maju serta kebutuhan pasar yang semakin tinggi membuat lembaga pendidikan berusaha lebih keras lagi dalam meningkatkan mutu dan kualitas pendidikan yang dimiliki oleh tenaga pendidik dan peserta didik guna mendapatkan output yang mampu bersaing diluar.

Daulat P Tampubolon (2001), secara rinci dan tegas mengemukakan bahwa mutu adalah paduan sifat-sifat produk yang menunjukan kemampuannya dalam memenuhi kebutuhan pelanggan langsung atau tak langsung, baik kebutuhan yang dinyatakan maupun yang tersirat masa kini dan masa depan. Dalam hubungan ini kebutuhan pelanggan dapat dijadikan kriteria atau standar mutu. Apabila hasil produk diatas standar dikatakan bermutu, sebaliknya apabila dibawah standar dikatakan tidak bermutu $^{1}$

Mutu pendidikan yang baik, bisa tercapai jika lembaga pendidikan tersebut mempunyai pemimpin yang mampu mengelola atau memberdayakan seumber dayanya dengan baik, pengelolaan sumber daya lembaga pendidikan sangat menentukan sampai mana ketercapaian suatu lembaga terhadap visi dan misi pendidikan didalam lembaga tersebut, maka oleh sebab itu peran kepala sekolah menjadi factor yang sangat berpengaruh terhadap pengembangan mutu dan kualitas pendidikan dalam suatu lembaga.

1 Triwahyu Budiutomo, "peningkatan mutu pendidikan melalui penilaian proses belajar mengajar" Academy Of Education Journal. Pendidikan Pancasila dan Kewarganegaraan Vol. 6 No. 1 Januari, (2015): hal, 55. 
Faktor yang mempengaruhi mutu pendidikan menurut Soedijarto (2008) meliputi proses pendidikan yang dialami peserta didik, ketersediaan sumber daya pendidikan termasuk di dalamnya tenaga pendidik, anggaran pendidikan, dan kebijakan yang merupakan hasil dari proses politik. Hal ini dipertegas oleh Sukmadinata (2008:7) yang menyatakan bahwa sekolah bermutu dipengaruhi oleh proses pendidikan yang bermutu dengan faktor pendukung, sarana dan prasarana dan biaya yang mencukupi, manajemen yang tepat, serta lingkungan yang mendukung ${ }^{2}$

Input, proses dan output adalah bagian terpenting didalam suatu lembaga, pendidikan yang perlu ditingkatkan mutu dan kualitasnya, input adalah peserta didik baru yang masuk kedalam lembaga pendidikan, proses adalah segala bentuk kegiatan yang dikelola dan dimanajemen didalam lembaga pendidikan tersebut sedangkan output adalah hasil yang mampu dicetak oleh lembaga pendidikan tersebut. Seumberdaya lembaga pendidikan adalah seluruh aspek yang berkaitan dengan lembaga pendidikan tersebut, baik itu tenaga pendidik maupun peserta didik, memahami mutu dan kualitas awal pada sumber daya lembaga pendidikan adalah salah satu cara untuk mengembangkan dan meningkatkan kualitas sumber daya lembaga pendidikan, diperlukan pemahaman secara mendalam terhadap sumber daya pendidikan untuk mengetahui aspek apa yang tepat untuk dikembangkan dan ditingkatkan.

Salah satu lembaga pendidikan yang penulis coba teliti adalah lembaga pendidikan islam Madrasah Tsanawiyah Assalam yang ada di kota Mataram Nusa Tenggara Barat, karena kebetulan sebelum melanjutkan study pascasarjana penulis sempat melakukan pengabdian menjadi tenaga pengajar disana selama satu tahun, sejauh pengamatan penulis dari lembaga pendidikan ini, cenderung mengedepankan nilainilai pendidikan islam guna meningkatkan kualitas dari peserta didik, melakukan kerjasama dengan beberapa lembaga pendidikan yang ada disekitar, melakukan pelatihan-pelatihan untuk guru, mengadakan kunjungan-kunjungan ke lembaga pendidikan yang sudah maju dan berkembang pesat, serta mengajukan permohonan tenaga pendidik pada lembaga pendidikan islam yang telah berkembang, yang sifatnya

${ }^{2}$ Siti Maamarah dan Supramono Supramono, "strategi peningkatan mutu dan citra (image)sekolab dasar negeri di ungaran, semarang," Kelola: Jurnal Manajemen Pendidikan 3, no. 1 (10 Juni 2016): hal, 116, https://doi.org/10.24246/j.jk.2016.v3.i1.p115-130. 
hanya sementara. Yayasan pondok pesantren Assalam dalam mengembangkan mutu dan kualitas dari sumber dayanya masih memegang teguh nilai-nilai al-Quran dan hadits, input peserta didik atau santri dilakukan dilakukan secara seleksi yang bersifat religius.

Untuk menganalisis input proses dan output dari suatu lembaga pendidikan, diperlukan sebuah pemahaman terhadap teori serta keadaan dilapangan dengan melakukan sebuah penelitian ilmiah yang nantinya akan memberikan suatu hasil yang kedepannya bisa bermanfaat bagi penulis dan juga objek penelitian itu sendiri.

\section{METODE PENELITIAN}

Penelitian ini merupakan salah satu penelitian kualitatif dengan menggunakan jenis pendekatan studi kasus "penelitian kualitatif adalah pengumpulan data pada suatu latar alamiah dengan maksud menafsirkan fenomena yang terjadi dimana peneliti adalah sebagai instrument kunci, pengambilan sampel sumber data dilakukan secara poruposive dan snowball, teknin pengumpulan dengan triangulasi (gabungan), analisis data bersifat induktif / kualitatif, dan hasil penelitian kualitatif lebih menekankan makna daripada generalisasi"3 "studi kasus adalah suatu penelitian ilmiah yang digunakan unutk meneliti secara mendalam suatu keadaan, fenomena atau kejadian yang dilakukan secara sistematis melalui penelaahan empiris pada suatu keadaan nyata dalam kehidupan(Bent Flyvbjerg, 2006, hlm. hal, 245)" adapun prosedur dalam penelitian ini adalah meredukasi data, penyajian data, dan verifikasi data, sdangkan teknik pengumpulan data dalam penelitian ini adalah dokumentasi dan observasi pada lembaga pendidikan MTs Assalam Kota Mataram NTB.

\section{HASIL DAN PEMBAHASAN}

Penelitian ini bertujuan untuk mengetahui mutu input, proses dan output dari lembaga pendidikan islam yang penulis coba lakukan di Madrasah Tsanawiyah Assalam Kota Mataram Nusa Tenggara Barat.

3 Albi Anggito \& Johan Setiawan, Model Penelitian Kualitatif, vol. 1 (Jln. Bojong ganteng Nomer 18, Kec.. Bojong ganteng, Kab. Sukabumu, Jawa Barat 43353: CV Jejak, 2018), hal, 8. 
a. Pengertian Mutu dan Kualitas Penidikan

Istilah "mutu" atau "kualitas" merupakan padanan dari istilah dalam bahasa Inggris, yakni quality, artinya, goodness or worth. Dengan demikian, secara definitif istilah mutu dapat diartikan sebagai kebaikan atau nilai. Istilah kata mutu dan kualitas sering kita temukan pada dunia ekonomi, kedua istilah ini melekat erat pada suatu produk barang atupun jasa yang dimana, pelangganlah yang menjadi penentunya.

Dalam konteks penelitian ini, mutu dan kualitas pendidikan dapat diartikan sebagai kemampuan manusia memberikan layanan kependidikan dalam rangka mencapai tujuan yang telah ditetapkan. Dengan kata lain, mutu pendidikan adalah suatu bentuk dari pencapaian luatu lembaga pendidikan guna memberikan atau memenuhi kebutuhan pasar atau. Dalam konteks pendidikan pengertian mutu, mengacu pada proses pendidikan dan hasil pendidikan.

Mutu dalam konteks"proses pendidikan" yang bermutu terlibat berbagai input, seperti; bahan ajar (kognitif, afektif, atau psikomotorik), metodologi (bervariasi sesuai kemampuan guru), sarana sekolah, dukungan administrasi, sarana prasarana, sumber daya lainnya serta penciptaan suasana yang kondusif. Manajemen kepala sekolah dalam menjalankan roda kepemimpinan pada suatu lembaga pendidikan sangat berfungsi mensinkronkan berbagai input tersebut atau mensinergikan semua komponen dalam interaksi (proses) belajar mengajar baik antara guru, siswa dan sumber daya yang ada pada sekolah tersebut, baik itu konteks kurikuler maupun ekstra-kurikuler, baik dalam lingkup subtansi yang akademis maupun yang nonakademis.

Mutu dalam konteks "hasil pendidikan" dilihatdari prestasi yang dicapai oleh sekolah tersebut dalam waktu tertentu (apakah tiap akhir cawu, akhir tahun, 2 tahun atau 5 tahun, bahkan 10 tahun). Prestasi yang dicapai atau hasil pendidikan (student achievement) juga bisa berupa hasil kemampuan (misalnya ulangan umum, UAS atau UN). Prestasi juga bisa didapatkan melalui bidang yang lain seperti di suatu cabang olah raga, seni atau keterampilan tambahan tertentu misalnya: komputer, beragam jenis teknik, jasa. Bahkan prestasi sekolah dapat berupa kondisi yang tidak dapat 
dipegang (intangible) seperti suasana disiplin, keakraban, saling menghormati, kebersihan ${ }^{4}$.

Institusi atau lembaga pendidikan yang efektif akan membutuhkan strategistrategi yang bertujuan dan kuat agar mampu meraih hasil yang kompetitif. (Sallis, 2012: 242$)^{5}$.

Kualitas pendidikan bermakna sama dengan mutu pendidikan keduanya perlu ditingkatkan, Peningkatan kualitas dan mutu pendidikan merupakan suatu proses yang terintegrasi dengan peroses peningkatan sumberdaya manusia itu sendiri ${ }^{6}$.

Dari pendapat diatas penulis mengambil sebuah asumsi, bahwa mutu dan kualitas pendidikan dalam lembaga pendidikan, adalah hasil dari suatu proses yang dilakukan oleh suatu lembaga pendidikan yang memberikan dampak besar terhadap penilaian masyarakat terhadap lembaga tersebut, yang kemudian akan memberikan dampak psitif bagi lembaga tersebut. Mutu dan kualitas pendidikan dapat dilihat dari pencapaian dari seluruh warga yang ada pada lembaga pendidikan tersebut, bisa peserta didik, guru, kepala sekolah dan bentuk-bentuk pengembangan aset seperti bidang ekonomi, industry, pertanian dan lain sebagainya.

Dari uraian tentang mutu dan kualitas diatas, maka penelitian yang coba penulis laksanakan di lembaga pendidikan MTs Assalam ini akan mencoba mengamati dan menganalisis secara mendalam bagaimana tingkat mutu serta kualitas yang ada pada lembaga tersebut.

\section{b. Pengertian Intput-Proses-Output Dalam Lembaga Pendidikan}

Pendidikan adalah usaha sadar yang dilakukan oleh keluarga, masayarakat dan pemerintah melalui kegiatan bimbingan, pengajaran dan atau latihan yang berlangsung di sekolah dan di luar sekolah untuk mempersiapkan peserta didik agar dapat memainkan peranannya dalam berbagai lingkungan hidup secara tepat di masa

4 Rahmat Hidayat, "manajemen peningkatan mutu lembaga pendidikan islam di kota medan," Jurnal Isema: Islamic Educational Management 1, no. 1 (23 Juni 2019): hal, 21, https://doi.org/10.15575/isema.v1i1.4982.

5 Syaefudin Syaefudin, "implementasi manajemen mutu terpadu (mmt) pada lembaga pendidikan islam (Studi Kasus di MI Unggulan Ash-Siddiqiyyah 3 Purworejo)," Jurnal Pendidikan Agama Islam 15, no. 2 (30 Desember 2018): hal, 228, https://doi.org/10.14421/jpai.2018.152-09.

${ }^{6}$ Rasdi Ekosiswoyo, "kepemimpinan kepala sekolah yang efektif kunci pencapaian kualitas pendidikan," Jurnal Ilmu Pendidikan, Jilid 14, Nomer 2, Juni (2007), hal, 76. 
yang akan datang(Kusnan, 2018, hlm. hal, 89). Lembaga pendidikan formal dalam menjalankan suatu proses yang didasari oleh tujuan dalam lembaga pendidikan tersebut, haruslah benar-benar memperhatikan dan memahami mutu dan kualitas input dan proses yang ada dalam lembaga tersebut, semakin baik manajemen input, proses dan output suatu lembaga pendidikan maka akan semakin besar pula peluang suatu lembaga pendidikan dalam mencapai tujuannya.

Pengertian input dalam bahasa berarti masukan, input juga bermakna masuk kedalam. Pengertian input dalam pendidikan berarti segala sesuatu yang harus tersedia karena dibutuhkan untuk berlangsungnya proses pendidikan, sesuatu itu bisa berupa sumber daya dan perangkat lunak, serta harapan-harapan dan masukanmasukan sebagai pemandu berjalannya sebuah proses. Maka dari itu input disini termasuk kepala sekolah, guru, staf, siswa, perlengkapan, peralatan, uang dan sebagainya. Manajemen Input dalam sebuah lembaga pendidikan pada dasarnya mencakup banyak hal. Beberapa diantaranya adalah input kurikulum, input sarana prasarana, input anak didik dan lain sebagainya ${ }^{7}$. Maka dari itu input dalam suatu lembaga pendidikan mempunyai makna yang luas meliputi hal yang bersifat material dan immaterial, input juga bisa berarti peserta didik yang baru masuk kedalam lembaga pendidikan tersebut, bisa juga perlengkapan-perlengkapan yang baru diadakan didalam lembaga tersebut, bisa juga tenaga pendidik yang baru masuk didalam lembaga tersebut.

Pengertian proses dalam KBBI adalah runtunan perubahan (peristiwa), bisa juga bermakna rangkaian tindakan, pengelolaan atau pengolahan, proses pendidikan adalah berubahnya sesuatu menjadi sesuatu yang lain. Proses dalam lembaga pendidikan berarti segala bentuk program kerja yang dilakukan selama berjalnnya pendidikan pada suatu lembaga pendidikan tersebut untuk merubah suatu nilai yang ada pada input menjadi lebih bernilai atau bermutu dan berkualitas, proses yang dilaksanakan dalam suatu lembaga haruslah bersifat mendidik untuk meningkatkan mutu dan kualitas peseta didik, proses itu senantiasa didasari dengan visi dan misi dari lembaga pendidikan,hal yang berkaitan erat dengan proses pendidikan adalah

7 Thorik Aziz, "manajemen input, proses, dan output paud berbasis alam(studi analisis di the jogja green school yogyakarta),’Jurnal Program Studi PGRA, volume 4, nomer 2, juli (2018), hal, 152. 
input, contohnya seorang guru yang professional, kemampuan guru dalam mengelola pembelajaran tidak terlepas dari profesionalisme dan kompetensi yang dimiliki oleh guru. Guru yang professional dan memenuhi kompetensi yang ditentukan, maka dia akan mampu mengelola pembelajaran dengan efektif dan efisien ${ }^{8}$.

Dalam lembaga pendidikan islam proses yang dimaksud bisa berupa pengelolaan kegiatan, pengambilan keputusan, pengelolaan lembaga, proses belajar mengajar, kegiatan-kegiatan ekstra, kegiatan monitoring, penilaian dan evaluasi. Hasil dari proses ini disebut output, yang menjadi sebuah pencapaian dari proses oleh input.

Output tidak akan pernah lepas dari penilaian dan evaluasi, penilaian atau evaluasi dalam pembelajaran sangat penting untuk dilakukan secara kontinyu. Indikator keberhasilan bukan merupakan sesuatu yang harus dicapai oleh anak, sehingga guru mencatat perkembangan anak sesuai apa yang ditemukan atau dilihat. Hal ini sesuai dengan pendapat Mansur (2007:47), yang menyebutkan bahwa penilaian autentik bukan mengahakimi anak, tetapi untuk mengetahui perkembangan pengalaman anak?

Pengertian output, dari segi bahasa adalah, hasil atau produk, jika kita tarik kedalam penegertian otput pendidikan, berarti suatu hasil yang di keluarkan oleh lembaga pendidikan, hasil ini bisa berupa, suatu kebijakan, lulusan, dan pengeluaran. Lembaga pendidikan meningkatkan mutu dan kualitas peserta didik untuk menghasilkan suatu output yang mampu berdaya saing di dunia luar, lembaga pendidikan yang baik, selalu memperhatikan peserta didiknya dari semenjak masuk menjadi siswa pada sekolah itu sampai dengan lulus dari sekolah tersebut. Output pendidikan adalah merupakan kinerja sekolah atau prestasi yang dihasilkan oleh sekolah tersebut, output dari suatu lembaga pendidikan dapat dilihat atau diukur dari kualitasnya, evektivitasnya, produktivitasnya, efisiendinya dan inovasinya, maka bisa dikatakan output dari suatu lembaga pendidikan itu berkualitas atau bermutu ketika pencapaian-pencapaian dari sekolah itu bernilai tinggi, entah itu pencapaian dari

8 I G K Artha, N Dantes, dan M Candiasa, “determinasi komponen konteks, input, proses, dan produk pelaksanaan program sekolah standar nasional (ssn) terhadap kualitas pelaksanaan pembelajaran para guru di smp negeri 2 kuta," e-Jurnal Program Pascasarjana Universitas Pendidikan Ganesha, volume 3 (2013), hal, 4. 9 Aziz, "manajemen input, proses, dan output paud berbasis alam(studi analisis di tk jogja green school yogyakarta)," hal, 156. 
prestasi belajar siswa, pencapaian guru-gurunya, dan pencapaian siswa dalam kegiatan-kegiatan ekstra.

Efektifitas pendidikan dapat dilihat dan diukur dari seberapa tinggi kualitas input, proses, dan outputnya. Institusi pendidikan dikatakan mempunyai tingkat kualitas input yang tinggi jika mempunyai kebijakan, tujuan dan sasaran mutu yang jelas, sumber daya tersedia dan siap, staf yang kompeten dan berdedikasi tinggi, mempunyai harapan prestasi yang tinggi, dan fokus pada pelanggan. Sedangkan lembaga pendidikan dikatakan mempunyai proses berkualitas apabila proses pembelajaran menekankan pada proses pemberdayaan peserta didik, kepemimpinan pendidikan yang kuat, lingkungan sekolah yang aman dan tertib, pengelolaan tenaga kependidikan yang efektif, mempunyai budaya mutu, ada teamwork yang kompak, mandiri, partisipasi civitas akademika dan masyarakat, responsif, transparan dan akuntabel. Selanjunya, output pendidikan dikatakan berkualitas jika mempunyai prestasi akademik (acadmic achievement) dan prestasi non akademik (non academic achievement) yang tinggi. Prestasi akademik dapat mencakup nilai hasil evaluasi belajar (IPK), karya ilmiah mahasiswa, hasil lomba bahasa, seni dan olah raga. Sedangkan prestasi non akademik dapat meliputi motivasi belajar dan berprestasi, solidaritas, toleransi, dan kerjasama inter dan antar lembaga(Kusnan, 2018, hlm. hal, 92).

Seperti peneliti paparkan diatas, dari beberapa hasil penelitian yang telah dilakukan oleh beberapa peneliti berkaitan tentang input, output dan proses, sebagian besar berbicara tentang SDM yang ada pada sekolah tersebut, bagaimana pelaksanaan pendidikannya, serta seperti apa hasil pencapaian yang di dapatkan oleh sekolah tersebut. Hal ini mengantarkan kita pada tujuan dari penelitian ini yaitu ingin mengetahui sejauh mana tingkat mutu dan kualitas yang ada pada lembaga pendidikan MTs Assalam.

\section{c. Pengertian Lembaga Pendidikan Islam}

Lembaga pendidikan islam secara umum adalah suatu wadah atau tempat menuntut ilmu yang tidak lepas dari aturan-aturan islam yaitu al-Quran dan hadits, lembaga pendidikan islam juga bisa diartikan sebagai suatu lembaga yang mempunyai pola-pola tertentu, dalam menjalankan proses pengelolaan manajemen pendidikan 
didalamnya, serta mempunyai struktur organisasi yang dapat mengikat individu yang berada pada naungannya sehingga mengantarkan lembaga ini mampu membuat hukumnya sendiri. "Pesantren merupakan salah satu jenis lembaga pendidikan Islam Indonesia yang bersifat tradisional dan juga modern untuk mendalami ilmu agama Islam, dan mengimpilimentasikannya dalam kehidupan sehari-hari dengan penekanan pada moral dalam hidup bermasyarakat" ${ }^{\prime 0}$. Pondok pesantren di Indonesia telah banyak menjadi contoh dalam keikut sertaannya dalam membnagun bangsa lewat berbagaimacam pencapaian-pencapaiannya dalam segala bidang, entah itu ekonomi, budaya dan pendidikan itu sendiri.

Lembaga pendidikan Islam harus dikelola dengan baik sehingga lembaga pendidikan Islam menjadi pilihan utama dan seluruh sumber daya manusia yang ada dalam lembaga merasa memiliki lembaga dan mau untuk berusaha bekerja keras demi berkembangnya lembaga tersebut ${ }^{11}$.

Berubahnya peradaban dan kebutuhan pasar di Indonesia, membuat para pemimpin-pemimpin dalam pondok pesantren terus mengembangkan segala bentuk program dan kegiatan yang ada didalmnya, sehingga mampu menjadikan santri dan para tenaga pendidik di dalam pondok pesntren tersebut mempunyai mutu dan kualitas yang bernilai tinggi bagi agama dan bangsa sehingga menjadi sebuah contoh yang bisa dijadikan model bagi pesantren yang lain. pondok pesantren memegang teguh nilai-nilai agama sebagai dasar atas kebijakan-kebijakan yang dikeluarkannya, namun bukan berarti nilai-nilai duniawi tidak digunakan begitu saja, telah banyak berkembnag di Indonesia saat ini pondok pesantren modern, yang dimana program kerja dan kegiatannya mengikuti perubahan zaman, pengelolaan yang dilakukan oleh pondok pesantren ini dikemas sebagaiman mestinya dan tidak keluar dari nilai-nilai agama islam.

Imam Ghazali berpendapat bahwa tujuan pendidikan Islam adalah kesempurnaan insan di dunia dan akhirat. Manusia akan mencapai keutamaan dengan menggunakan ilmu, dengan ilmu maka manusia akan diangkat derajatnya oleh Allah SWT,

${ }^{10} \mathrm{KM}$ Akhiruddin, "Lembaga Pendidikan Islam di Nusantara" Jurnal Tarbiyah Volume 1, no. 1 (2015): hal, 1.

${ }^{11}$ Erwin Indrioko, "lembaga pendidikan islam dalam menghadapi derasnya perubahan," Jurnal, Volume 3, no 1, juli (2016), hal, 63. 
begitupun sebaliknya manusia tanpa ilmu akan diremehkan, ilmu dunia dan akhirat yang perlu ditanamkan kepada manusai. Pendapat Imam Ghazali ini sejalan dengan sabda Nabi SAW yang artinya : "Siapa yang ingin hidup di dunia dengan baik hendaklah ia berilmu, dan siapa yang ingin meraih kebahagiaan di akherat hendaklah ia berilmu, dan siapa yang ingin meraih keduanya (dunia dan akherat) hendaklah ia berilmu”. (HR. Ahmad)(Sirojudin, 2019, hlm. hal, 207).

Maka lembaga pendidikan islam hendaknya berlandaskan al-quran dan hadis sebagai pondasi awal dalam membangun, mengembangkan dan mengelola sebuah lembaga pendidikan islam yang bermutu dan berkualitas, lalu dikembangkan sesuai peradaban atau perkembangan zaman, namun tidak keluar dari aturan-aturan yang sudah ditetapkan oleh Allah dalam al-Quran dan hadits.

d. Analisis Mutu Input, Proses, dan Output Lembaga Pendidikan MTs Assalam Input dalam pendidikan berarti segala sesuatu yang harus tersedia karena dibutuhkan untuk berlangsungnya proses pendidikan Pada tahun 2016 awal Tgh, H. Mukarram Fadli memulai untuk merintis Lembaga Pendidikan Madrasah Tsanawiyah, Input peserta didik diawali dari santri yang sudah lulus SD dan menjadi santri pada TPQ Assalam, input awal dilakukan dengan metode jemput bola yaitu mencari sendiri anak-anak yang mau dan berkeinginan kuat untuk sekolah, belajar agama dan mau mondok, tanpa dipungut biaya, orang tua hanya mendukung anaknya untuk menuntut ilmu di pondok pesantren Assalam, metode yang lain juga dilakukan dengan cara menanyakan anak-anak lulusan SD atau MI yang menjadi santri TPQ Assalam, untuk melanjutkan sekolah di sana, walau tidak semua mau untuk melanjutkan sekolahnya di MTs Assalam namun hal itu tidak menurunkan semangat Beliau untuk membangun lembaga pendidikan MTs, pada awal tahun 2017 MTs Assalam mendaptkan murid 15 orang yaitu dari Kabupaten Lombok Utara, Barat Tengah dan dari Bima, namun seiring berjalannya waktu, beberapa diantara mereka tidak sanggup melanjutkan sekolah disana sampai yang berhasil melewati satu masa periode hanya 10 orang.

Input tenaga pendidik diawali dengan cara mengajak keluarga menjadi tenaga pengajar di lembaga tersebut, rekrutmen tenaga pendidik trus disebarkan sampai ada pula mahasiswa yang masih aktip dalam kulianya ikut serta mngabdikan diri menjadi 
tenaga pengajar didalam pondok pesantren Assalam, karena prose pendidikan yang ada disana terbagi menjadi dua, yaitu pendidikan berbasis sekolah dan pondok, keduanya saling melengkapi, jadi keduanya mempunyai penilaian secara terpisah, ada mata pelajaran sekolah dan ada mata pelajaran pondok, yang diajarkan dalam kegiatan diniyah dimalam hari, kegiatan diniyah menggunakan kelas dan masjid sebagai tempat pembelajarannya, tenaga pendidik juga berasal dari santri Pondok Pesantren Nurul Haramain Narmada Lombok Barat. Pengadaan sarana dan prasarana seperti meja, bangku, ruangan kelas dan lain sebagainya di dapatkan melalui pengajuan proposal ke beberapa kantor pemerintahan, iyuran masyarakat, bantuan dari lembagalembaga pendidikan yang telah berkembang yang kebetulan adalah kerabat baik dari pimpinan pondok Assalam.

Proses pendidikan yang dirancang sebagai suatu usaha mencapai pendidikan dan output yang bermutu dan berkualitas maka dilakukan berbagai macam usaha diantaranya diadakannya kunjungan atau study banding ke pondok-pondok modern satu alumni gontor yang sudah maju dan berkembang pesat, manajemen dan pencapaian yang diraih oleh kedua pondok itu menjadi salah satu motivasi yang mendorong semangat untuk terus meningkatkan mutu dan kualitas pada pondok pesantren Assalam, Adapun beberapa kebijakan yang diterapkan disana adalah wajib tinggal di pondok dan mengikuti aturan pondok, wajib berpuasa sunnah hari senin dan kamis, sedangkan bentuk usaha meningkatkan mutu dilakukan dengan cara mengadakan kerjasama dengan pondok-pondok lain, melakukan kerjasama dengan masyarakat, mengadakan pengajian untuk masyarakat, selalu berkordinasi dengan wali santri dan membangun jaringan dengan tenaga kerja kantor wilayah. Tgh,H.Mukarram Fadli yang menjadi salah satu alumni Pondok Pesantren Gontor Ponorogo Jawa Timur, menanamkan nilai-nilai ponodok pesantren yang sesuai dengan backgroundnya, system pengelolaannya juga menggunakan system gontor, namun selalu menyesuaikan dengan kondisi yang ada disana. Santri yang wajib mondok, tidak dibebankan biaya pendidikan, makan masih ditanggung oleh pihak pondok, dana yang didapatkan untuk semua itu didapatkan dari pihak masyarakat yang memang telah merasa dekat dengan yayasan itu, seperti pejabat-pejabat yang tinggal di BTN Lendang lekong, infaq sodaqoh, dari luar, pengajuan proposal, dan 
sumbangan dari orang tua wali santri itu sendiri. Kegiatan harian yang diterpakan dari jam 04.00 sampai dengan jam 22.00, dikemas atau dirancang dengan kegiatankegiatan yang bernilai religius, dan menyenangkan, dalam proses pelaksanaanya kembali kepada seni mendidik para tenaga pendidik yang ada disana, adapun beberapa kegiatan rutinitas harian yang dilakukan oleh santri yaitu salat secara berjamaah, belajar dikelas, makan bersama, muhadasah, muhadaroh, kegiatan olah raga, kegiatan eskul pramuka, dan pengajian setiap hari sabtu sore. Kegiatan memasak dilakukan secara bersama dengan santri, bertujuan untuk melatih kemandirian para santri dan membiasakan hidup sederhana, semua pekerjaan pembangunan gedung juga harus melibatkan semua santri yang bertujuan untuk menanamkan rasa cinta kepada pondok dan ikut merasakan menjadi seorang perintis pondok, dalam setiap pembelajaran di kelas maupun di pondok, selalu diingatkan dan diselipkan materi tentang pengabdian pada pondok pesantren, semua itu untuk menanamkan jiwa pengabdian pada pondok pesantren yang nanti pada akhir masa periode lulus sekolah mereka tidak perlu diminta untuk mengabdi namun mereka mereka yang akan meminta untuk selalu mengabdi untuk pondok pesantren Assalam dikarenakan mereka merasakan kenyamanan dan kekeluargaan ketika hidup di pondok Assalam.

Mutu pendidikan di pondok pesantren assalam dikelola dengan tujuan membentuk santri yang memiliki jiwa serta karakter iman dan taqwa. Salah satu bentuk proses yang dibiasakan adalah mendisiplinkan para siswa dalam mentaati jadwal yang telah dibuat sampai pada disiplin dalam melaksanakan shalat berjamaah, menjalin hubungan erat dengan masyarakat sekitar, para wali santri dan komponenkomponen lain sebagainya. Sebab dalam sistem pendidikan nasional sekarang ini, mutu dan kualitas pendidikan adalah hasil dari sinergi antara lembaga pendidikan terkait, masyarakat, lembaga pemerintah, kantor-kantor pemerintahan dan para wali murid. Untuk melaksanakan penjaminan mutu tersebut, diperlukan kegiatan yang sistematis dan terencana dalam bentuk manajemen mutu(Winarsih, 2017, hlm. hal, 54).

Output adalah sebuah hasil pencapaian dari suatu lembaga pendidikan, sesuai dari pengertian dan salah satu tujuan dari penelitian ini yaitu untuk mengetahui sejauh mana output pada pendidikan MTs Asalam, pada umumnya sebuah lembaga yang 
memiliki input yang memadai dan menjalankan proses dengan efisien besar kemungkinan akan mendapatkan output yang bermutu dan berkualitas. Lembaga pendidikan MTs Assalam dalam pengelolaan sumber daya yang ada disana menanamkan jiwa iman dan taqwa, yaitu berpegang teguh pada al-Quran dan hadits, dimana salah satu program yang diunggulkan yaitu program tahfidz al-Quran, kedua adalah bagaimana hidup mandiri, aktip, semanagat, mempunyai motivasi belajar tinggi, mempunyai rasa ingin tau dan lain sebagainya, hal ini terlihat dari antusias para peserta didik dalam menjalankan proses pendidikan yang ada pada sekolah maupun pondok pesantren, salah satu untuk mengukurnya yaitu motivasi dan semangat para peserta didik ketika mengikuti lomba menghapal al-Quran, pidati bahasa Indonesia, inggris dan bahasa Arab yang di adakan oleh pondok maupun menjadi peserta keluar pondok. Selanjutnya dukungan dari masyarakat sekitar yang merasa bangga atas pencapaian yang telah di dapatkan oleh para peserta didik termasuk juga keikut sertaan orang tua wali dalam mendukung seluruh program yang diadakan oleh pondok dan sekolah.

\section{KESIMPULAN}

1. Lembaga pendidikan MTs Assalam adalah lembaga pendidikan yang mengelola pendidikan berdasarkan al-Quran dan hadits sesuai dengan pedoman hidup yang diterapkan dilingkunagn pondok pesantren diluar sekolah. Mutu dan kualitas dari lembaga pendidikan MTs Assalam adalah nilai yang melekat dari suatu proses pengelolaan sumber daya lembaga pendidikan itu sendiri, contohnya berupa pencapaian-pencapaian yang diraih oleh lembaga pendidikan.

2. Input, proses dan output di lembaga pendidikan MTs Assalam adalah suatu bagian atau sumber daya dalam lembaga pendidikan yang perlu ditingkatkan.

3. Pengelolaan dan manajemen untuk meningkatkan mutu dari sumber daya lembaga pendidikan MTs Assalam entah itu mutu dalam sebuah input, proses maupun output dilakukan setiap tahunnya seperti menarik minat peserta didik baru melalui segala bentuk kegiatan ekstra, meminta tenaga pendidik dari 
lembaga pendidikan atau pondok pesantren cabang gontor dan melakukan kegiatan-kegiatan keagamaan yang ditujuakan untuk masyarakat sekitar.

\section{DAFTAR PUSTAKA}

Akhiruddin, K. (2015). Lembaga Pendidikan Islam di Nusantara. 1 no 1, 25. http://journal.uinsgd.ac.id/index.php/jurnal-tarbiyah/articel/view/143

Albi Anggito \& Johan Setiawan. (2018). Metode Penelitian Kualitatif (Vol. 1). CV Jejak.

Artha, I. G. K., Dantes, N., \& Candiasa, M. (2013). Determinasi komponen konteks, input, proses, dan produk pelaksanaan program sekolah standar nasional (ssn) terhadap kualitas pelaksanaan pembelajaran para guru di smp negeri 2 kuta. 12.

Aziz, T. (2018). Manajemen input, proses, dan output paud berbasis alam(studi analisis di the jogja green school yogyakarta). 4 no $2, \quad 9$. http://doi.org.http// doi.org/10.29062/sliving.v4i2.303

Bent Flyvbjerg. (2006). Lima Kesalahpahaman Tentang Penelitian Studi Kasus (Vol. 12).

Budiutomo, T. (2015). Peningkatan mutu pendidikan melalui penilaian proses belajar mengajar. 6(1), 13.

Ekosiswoyo, R. (2007). Kepemimpinan kepala sekolah yang efektif kunci pencapaian kualitas pendidikan. 14 no 2, 7. http://journal.um.ac.id/index.php/jip

Hidayat, R. (2019). Manajemen peningkatan mutu lembaga pendidikan islam di kota medan. Jurnal Isema: Islamic Educational Management, 1(1). https://doi.org/10.15575/isema.v1i1.4982

Indrioko, E. (2016). Lembaga pendidikan islam dalam menghadapi derasnya perubahan. 3 no 1,16. http://ejournal.staimadiun.ac.id/index.php/annuha/articel/view/63

Kusnan, K. (2018). Analisis Outcome Pendidikan: Kontribusi Lulusan Program Studi PAI Pada Madrasah dan Sekolah Menengah di Kota Manado. Jurnal Ilmiah Iqra', 9(1). https://doi.org/10.30984/jii.v9i1.600

Maamarah, S., \& Supramono, S. (2016). Strategi peningkatan mutu dan citra (image)sekolah dasar negeri di ungaran, semarang. Kelola: Jurnal Manajemen Pendidikan, 3(1), 115. https://doi.org/10.24246/j.jk.2016.v3.11.p115-130

Sirojudin, A. (2019). Manajemen Pendidikan Madrasah Ibtidaiyah. MODELING: Jurnal Program Studi PGMI, 6(2), 204-219. https://doi.org/10.36835/modeling.v6i2.162

Syaefudin, S. (2018). Implementasi manajemen mutu terpadu (mmt) pada lembaga pendidikan islam (Studi Kasus di MI Unggulan Ash-Siddiqiyyah 3 Purworejo). Jurnal Pendidikan Agama Islam, 15(2), 150-168. https://doi.org/10.14421/jpai.2018.152-09

Winarsih, S. (2017). Kebijakan dan Implementasi Manajemen Pendidikan Tinggi dalam Meningkatkan Mutu Pendidikan. Cendekia: Journal of Education and Society, 15(2), 51. https://doi.org/10.21154/cendekia.v15i2.1005 